NASA/TM-2004-213188

\title{
Further Investigations of Hypersonic Engine Seals
}

Patrick H. Dunlap, Jr. and Bruce M. Steinetz

Glenn Research Center, Cleveland, Ohio

Jeffrey J. DeMange

University of Toledo, Toledo, Ohio 
Since its founding, NASA has been dedicated to the advancement of aeronautics and space science. The NASA Scientific and Technical Information (STI) Program Office plays a key part in helping NASA maintain this important role.

The NASA STI Program Office is operated by Langley Research Center, the Lead Center for NASA's scientific and technical information. The NASA STI Program Office provides access to the NASA STI Database, the largest collection of aeronautical and space science STI in the world. The Program Office is also NASA's institutional mechanism for disseminating the results of its research and development activities. These results are published by NASA in the NASA STI Report Series, which includes the following report types:

- $\quad$ TECHNICAL PUBLICATION. Reports of completed research or a major significant phase of research that present the results of NASA programs and include extensive data or theoretical analysis. Includes compilations of significant scientific and technical data and information deemed to be of continuing reference value. NASA's counterpart of peerreviewed formal professional papers but has less stringent limitations on manuscript length and extent of graphic presentations.

- TECHNICAL MEMORANDUM. Scientific and technical findings that are preliminary or of specialized interest, e.g., quick release reports, working papers, and bibliographies that contain minimal annotation. Does not contain extensive analysis.

- CONTRACTOR REPORT. Scientific and technical findings by NASA-sponsored contractors and grantees.
- CONFERENCE PUBLICATION. Collected papers from scientific and technical conferences, symposia, seminars, or other meetings sponsored or cosponsored by NASA.

- SPECIAL PUBLICATION. Scientific, technical, or historical information from NASA programs, projects, and missions, often concerned with subjects having substantial public interest.

- TECHNICAL TRANSLATION. Englishlanguage translations of foreign scientific and technical material pertinent to NASA's mission.

Specialized services that complement the STI Program Office's diverse offerings include creating custom thesauri, building customized databases, organizing and publishing research results ... even providing videos.

For more information about the NASA STI Program Office, see the following:

- Access the NASA STI Program Home Page at http://www.sti.nasa.gov

- E-mail your question via the Internet to help@sti.nasa.gov

- Fax your question to the NASA Access Help Desk at 301-621-0134

- Telephone the NASA Access Help Desk at 301-621-0390

- Write to:

NASA Access Help Desk

NASA Center for AeroSpace Information 7121 Standard Drive

Hanover, MD 21076 
NASA/TM-2004-213188

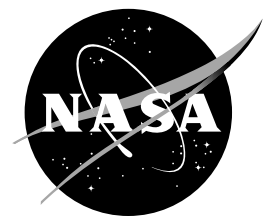

Further Investigations of Hypersonic Engine Seals

Patrick H. Dunlap, Jr. and Bruce M. Steinetz

Glenn Research Center, Cleveland, Ohio

Jeffrey J. DeMange

University of Toledo, Toledo, Ohio

Prepared for the

40th Joint Propulsion Conference and Exhibit

cosponsored by the AIAA, ASME, SAE, and ASEE

Fort Lauderdale, Florida, July 11-14, 2004

National Aeronautics and

Space Administration

Glenn Research Center 


\section{Acknowledgments}

The authors gratefully acknowledge Dick Tashjian (QSS Group, Inc.) and Shawn Taylor (CWRU) for their assistance in test support.

Trade names or manufacturers' names are used in this report for identification only. This usage does not constitute an official endorsement, either expressed or implied, by the National Aeronautics and Space Administration.

Available from

NASA Center for Aerospace Information 7121 Standard Drive

Hanover, MD 21076
National Technical Information Service 5285 Port Royal Road Springfield, VA 22100

Available electronically at http:/ /gltrs.grc.nasa.gov 


\title{
Further Investigations of Hypersonic Engine Seals
}

\author{
Patrick H. Dunlap, Jr. and Bruce M. Steinetz \\ National Aeronautics and Space Administration \\ Glenn Research Center \\ Cleveland, Ohio 44135 \\ Jeffrey J. DeMange \\ University of Toledo \\ Toledo, Ohio 43606
}

\begin{abstract}
Durable, flexible sliding seals are required in advanced hypersonic engines to seal the perimeters of movable engine ramps for efficient, safe operation in high heat flux environments at temperatures of 2000 to $2500{ }^{\circ} \mathrm{F}$. Current seal designs do not meet the demanding requirements for future engines, so NASA's Glenn Research Center is developing advanced seals and preloading devices to overcome these shortfalls. An advanced ceramic wafer seal design and two silicon nitride compression spring designs were evaluated in a series of compression, scrub, and flow tests. Silicon nitride wafer seals survived 2000 in. $(50.8 \mathrm{~m})$ of scrubbing at $2000{ }^{\circ} \mathrm{F}$ against a silicon carbide rub surface with no chips or signs of damage. Flow rates measured for the wafers before and after scrubbing were almost identical and were up to 32 times lower than those recorded for the best braided rope seal flow blockers. Silicon nitride compression springs showed promise conceptually as potential seal preload devices to help maintain seal resiliency.
\end{abstract}

\section{Introduction}

High temperature, dynamic structural seals are required in advanced hypersonic engines to seal the perimeters of movable engine ramps for efficient, safe operation in high heat flux environments at temperatures from 2000 to $2500^{\circ} \mathrm{F}$. Seals must be flexible enough to accommodate distorted walls and provide positive, resilient sealing. They also must be sufficiently durable to meet required engine life goals.

NASA Glenn Research Center (GRC) became involved in the development of high temperature structural seals in the late 1980's and early 1990's during the National Aerospace Plane (NASP) program. Researchers at GRC (then called the Lewis Research Center) carried out an inhouse program to develop seals for the NASP hypersonic engine and oversaw industry efforts for airframe and propulsion system seal development for this vehicle. ${ }^{1}$ Figure 1 shows one of the seal locations in the NASP engine. Seals were needed along the edges of movable panels in the engine to seal gaps between the panels and adjacent engine sidewalls. Seal development efforts undertaken during the NASP program became the basis for current seal development activities at GRC to meet the seal challenges of future hypersonic and reentry vehicles.

Seals developed during the NASP program met many requirements but fell short of leakage, durability, and resiliency goals. Due to program termination the seals could not be adequately matured. To overcome these shortfalls, GRC is currently developing advanced seals and seal preload devices for the hypersonic engines of future space vehicles as part of NASA's Next Generation Launch Technology (NGLT) program.

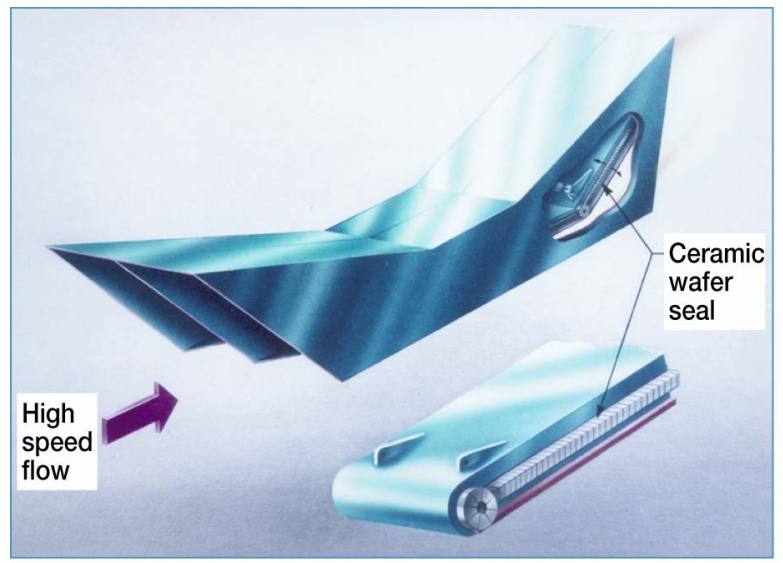

Figure 1. NASP engine panel edge seals designed to seal the gaps between the movable ramps and adjacent engine sidewalls. 


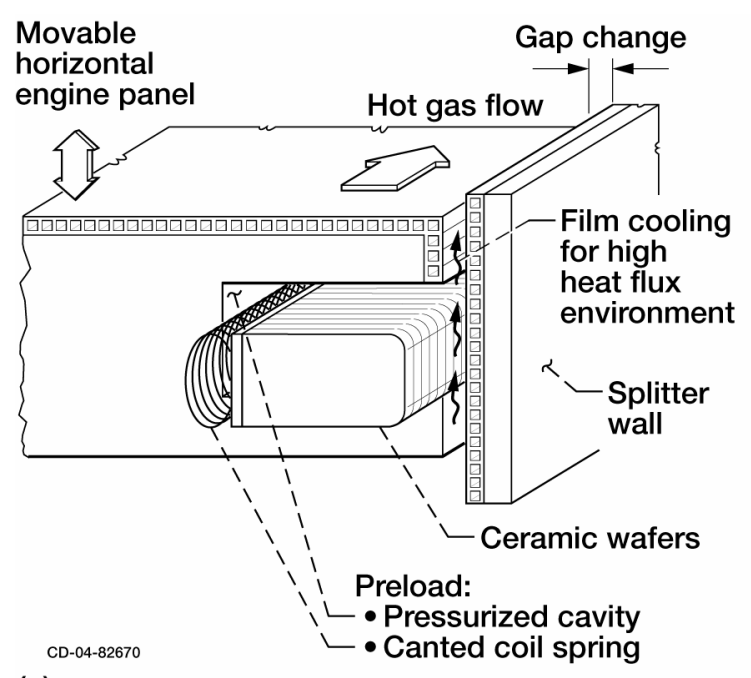

(a)

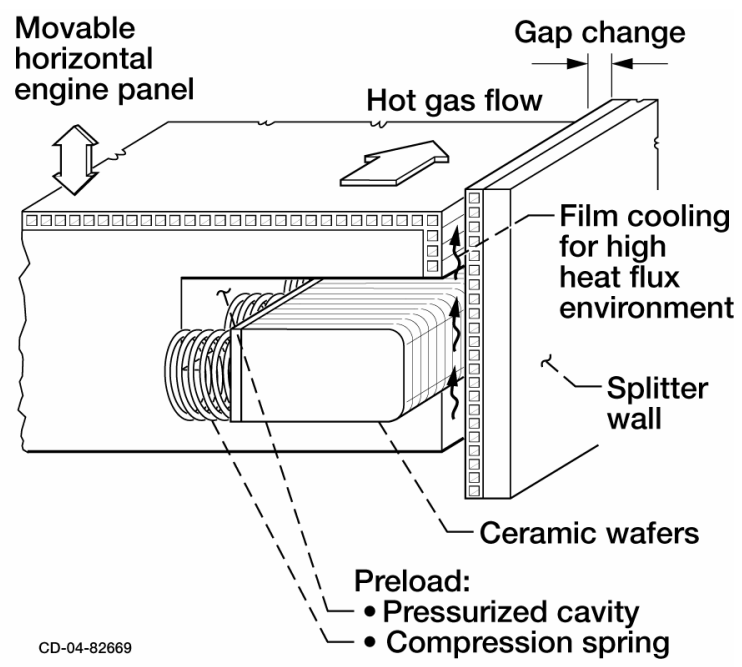

(b)

Figure 2. Schematics of ceramic wafer seal designed to seal the gaps between the edges of movable ramps and adjacent engine sidewalls with (a) canted coil springs or (b) compression springs as preload devices.

\section{A. Challenges and Objectives for Seal Development}

High temperature structural seals have been identified as a critical technology in the development of future space vehicles. Seals in hypersonic propulsion systems are expected to reach very high temperatures and operate in a chemically hostile environment in which oxidation and hydrogen embrittlement can occur. Analyses of panel-edge seals in the inlet of the NASP engine predicted seal temperatures of up to $2100{ }^{\circ} \mathrm{F}$. However, similar seals in the entrance region of the NASP engine combustor were expected to reach temperatures as high as $4900^{\circ} \mathrm{F}$ at Mach 10. Even higher temperatures were possible if the vehicle stayed in scramjet mode for a longer time at higher Mach numbers. Because no existing materials could withstand those temperatures, active cooling of the seals was planned to ensure that they would survive in the combustor and nozzle regions. A cooling system inevitably comes with a weight penalty due to the plumbing lines, tanks, valves, and coolant gas that would be required. Ideally future propulsion system seals would operate at the flowpath temperature without coolant. However, the presence of steam and an oxidizing environment limits uncooled seal temperatures to the upper use temperatures of modern engineering ceramic materials. In regions where gas temperatures exceed material limits, some use of active cooling will be required.

In addition to operating at very high temperatures, seals must also remain resilient after repeated loading to ensure that they stay in contact with their sealing surfaces and restrict the flow of hot gases. Different techniques have been considered to keep seals in contact with their sealing surfaces including pressurized cavities, bellows, and springs behind the seals. Figure 2 illustrates two different spring designs being considered as seal preload devices. As part of this effort, novel high temperature seal preload devices are being evaluated to develop robust, reusable sealing systems that can operate at higher temperatures for longer periods of time while still remaining resilient. The objective is to produce a sealing system that would have a permanent set of less than 20 percent of its stroke at $2000+{ }^{\circ} \mathrm{F}$. These advanced seals and preload devices will be evaluated and their performance will be demonstrated through testing in simulated environments to ultimately develop seal systems that fill this technology gap.

\section{B. Seal Design Requirements}

Hypersonic engine seals have a demanding set of design requirements as shown in Table 1. For near term applications in X-vehicle demonstrators, seal temperatures of $1600{ }^{\circ} \mathrm{F}$ are anticipated. As engine systems are developed for the final vehicles, seal temperatures are expected to increase to as much as 2000 to $2500{ }^{\circ} \mathrm{F}$. To meet engine performance, safety, and life goals, the seals must withstand these extreme temperatures with minimal active cooling to limit the need for complex, heavy seal purge cooling systems. Inlet mass addition caused by purge cooling the seals could affect inlet performance and stability thereby increasing the chance of engine unstart. Because of this, hypersonic engine inlet designers would prefer inlet seals that do not require purge cooling. Furthermore, engine seals must limit the leakage of hot, pressurized ( $\sim 100 \mathrm{psi})$ gases and unburned propellant into 
Table 1. Hypersonic engine seal design requirements.

\begin{tabular}{|l|c|}
\hline \multicolumn{1}{|c|}{ Design Requirement } & Goal \\
\hline Seal temperature: near term for X-vehicle demonstrator & $1600^{\circ} \mathrm{F}$ \\
\hline Seal temperature: longer term for final vehicle engine system & 2000 to $2500^{\circ} \mathrm{F}$ \\
\hline Gas temperatures near seal & $\sim 5000^{\circ} \mathrm{F}$ \\
\hline Pressure drop across seal & Minimize \\
\hline Leakage & Up to 2000 Btu/ $\mathrm{ft}^{2}$-sec \\
\hline Heat flux & $\begin{array}{c}\text { Oxidizing and steam environment; } \\
\text { possible hydrogen embrittlement }\end{array}$ \\
\hline Environmental considerations & Prefer to operate without active cooling \\
\hline Use of cooling: Inlet & Operate with minimal cooling \\
\hline Use of cooling: Combustor and nozzle & $\sim 2500$ sec ( 42 min) \\
\hline Flight time & TBD - nominally 10 to 100 cycles \\
\hline Reusability & $\begin{array}{c}\text { Accommodate engine side wall } \\
\text { non-uniformities and distortions }\end{array}$ \\
\hline Flexibility & $\begin{array}{c}\text { Accommodate seal gap openings and closings } \\
\text { Resiliency }\end{array}$ \\
\hline Seal gap size & $\begin{array}{c}0.03 \text { in. to 0.15 in.; } \\
\text { gap variation of 0.15 in. over 18 in. span (Ref. 1) }\end{array}$ \\
\hline Sliding speed & 2 in./sec \\
\hline Wear resistance & Withstand scrubbing against rough surfaces \\
\hline
\end{tabular}

backside cavities to prevent explosive mixtures from forming there. The seals must operate in an oxidizing/steam environment and resist hydrogen embrittlement if hydrogen is used as a propellant. Structural and thermal loads on the engine sidewalls can cause distortions that the seals must accommodate. To stay in contact with the walls, the sealing system must remain resilient and flexible for multiple heating cycles. The seals will also be rubbed over these distorted, rough walls as the engine panels holding the seals are actuated. The seals must survive the hot scrubbing without incurring increases in leakage due to wear.

\section{Seal Preload Devices}

\section{Requirements}

The high temperature seal preload devices that are being developed and evaluated would be installed

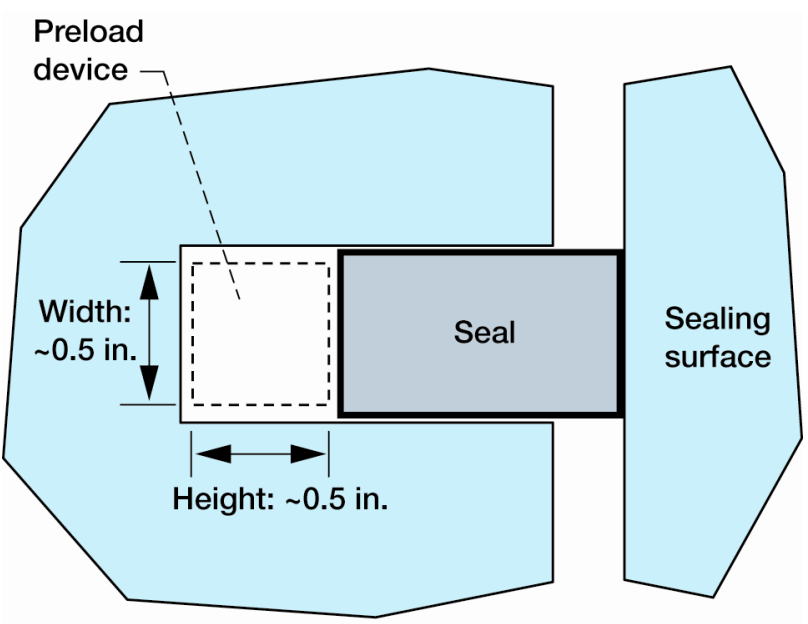

Figure 3. Cross sectional model of seal showing location and space limitations for preload device. behind the seals to ensure sealing contact with the opposing sealing surfaces (Fig. 3). The requirements for these devices are also quite challenging. They must operate in the same environment and temperature as the seals while providing the required stroke (nominally 0.1 in.) with a permanent set of less than 20 percent of that stroke for multiple loading and heating cycles. Complicating this effort further is the limited amount of space available for the preloader behind the seals. The cross sectional area of the device must fit in a space approximately $0.5 \mathrm{in}$. wide by $0.5 \mathrm{in}$. high. Ideally the device would be about as long as the seal and able to be installed around corners. The device must be stiff enough to support the seal and keep it pressed against the sealing surface but soft enough that it does not apply excessive loads to that surface.

\section{Candidate Designs}

As shown in Fig. 2, two different seal preload device designs are being considered. The first approach is a canted coil spring that was evaluated in a previous study by Dunlap et al. ${ }^{3}$ and is shown in Figs. 2(a) and 4. These springs have several unique features that could make them very good seal preload devices. Unlike typical compression springs that generate increasing amounts of force as they are compressed, the force produced by canted coil springs remains nearly constant over a large deflection range. Figure 4 presents load versus deflection data 


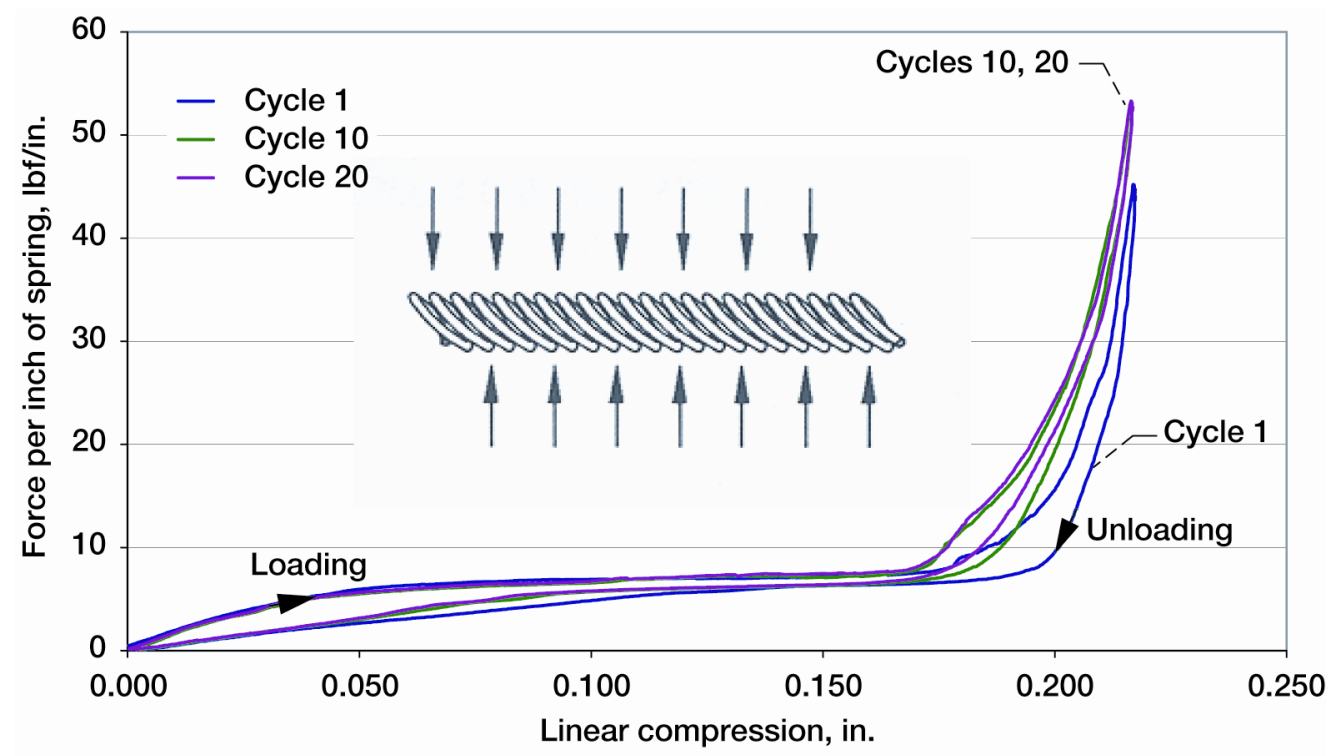

Figure 4. Load vs. linear compression for canted coil spring at room temperature (load cycles other than 1, 10, and 20 removed for clarity).

previously reported by Dunlap et al. ${ }^{3}$ for a canted coil spring including the portion of the curve where the load levels off and becomes nearly constant. This is an appealing feature for a seal preload device because it could provide a large amount of stroke and resiliency to a seal without applying excessive loads to the seal or the opposing sealing surfaces. Another study by Dunlap et al. ${ }^{4}$ reported on the development of high temperature versions of these springs. High temperature silicon nitride compression springs, shown schematically in Fig. 2(b), are also being evaluated for this application. The tests performed to evaluate these springs will be described in more detail in subsequent sections of this paper.

\section{Test Apparatus and Procedures}

\section{A. Seal Specimens}

Ceramic wafer seals were originally developed during the NASP program. ${ }^{2,5}$ They are composed of a series of thin ceramic wafers installed in a channel on a movable panel and preloaded from behind to keep them in contact with the opposing sealing surface (Figs. 2 and 3). Materials that were evaluated for the wafer seals during the NASP program included a cold-pressed and sintered aluminum oxide, a sintered alpha-phase silicon carbide, a hotisostatically-pressed silicon nitride, and a cold-pressed and sintered silicon nitride. ${ }^{6}$ Early wafers were made from silicon carbide and aluminum oxide. The corners of the silicon carbide wafers chipped off during static flow tests. It was believed that these chips originated from inclusions and impurities found near the wafer corners. Aluminum oxide wafers exhibited edge chipping during aggressive dynamic scrubbing and flow tests in a follow-on program. A detailed analytical comparison of all the materials that were considered ranked the advanced silicon nitride ceramics as the most promising material for future consideration. ${ }^{6}$

Given that these tests were performed in the late 1980's, considerable improvements have been made since then to produce stronger and tougher ceramic materials. Because of these improvements and the high ranking of silicon nitride as a candidate wafer seal material, silicon nitride was selected as the best candidate for these seals. The wafers tested in the current study were made of monolithic silicon nitride (Honeywell AS800) and were 0.5-in. wide, 0.92 -in. tall, and 0.125 in. thick. They had corner radii of $0.050 \mathrm{in}$. A series of tests were conducted to characterize the performance of these seals including room and high temperature compression and scrub tests and room temperature flow tests on the seals before and after the scrub tests. 
Table 2. Design specifications for seal preload devices.

\begin{tabular}{|l|c|c|c|c|c|c|c|}
\hline \multicolumn{1}{|c|}{ Spring design } & Material & $\begin{array}{c}\text { Part } \\
\text { number }\end{array}$ & $\begin{array}{c}\text { Wire } \\
\text { diameter, } \\
\text { in. }\end{array}$ & $\begin{array}{c}\text { Coil } \\
\text { height, } \\
\text { in. }\end{array}$ & $\begin{array}{c}\text { Coil } \\
\text { width, } \\
\text { in. }\end{array}$ & $\begin{array}{c}\text { Max. } \\
\text { deflection, }{ }^{\text {a }} \\
\text { in. }\end{array}$ & $\begin{array}{c}\text { Max. } \\
\text { load, }{ }^{\mathrm{a}} \text { lbf }\end{array}$ \\
\hline $\begin{array}{l}\text { NHK standard } \\
\text { compression spring }\end{array}$ & $\begin{array}{c}\text { Silicon } \\
\text { nitride }\end{array}$ & $\begin{array}{c}\text { NCS2- } \\
\text { 025S }\end{array}$ & 0.065 & 0.815 & 0.520 & 0.098 & 5.5 \\
\hline $\begin{array}{l}\text { NHK modified } \\
\text { compression spring }\end{array}$ & $\begin{array}{c}\text { Silicon } \\
\text { nitride }\end{array}$ & $\begin{array}{c}\text { NCSS- } \\
\text { 02618DOB }\end{array}$ & 0.065 & 0.720 & 0.435 & 0.043 & 5.5 \\
\hline
\end{tabular}

${ }^{\mathrm{a}}$ Per manufacturer's specifications.

\section{B. Seal Preload Device Specimens}

The seal preload device evaluated in this study was a silicon nitride compression spring produced by NHK Spring Co., Ltd. Two different designs were tested: a standard spring and a modified design. Design specifications from the manufacturer for these springs are given in Table 2. Because they are made of silicon nitride, these springs have the potential to be used as high temperature seal preload devices. Product literature claims that the strength of these springs will not decrease significantly at service temperatures up to $1832{ }^{\circ} \mathrm{F}$ and that the strength maintains a level of $29 \mathrm{ksi}$ with a failure probability of 0.1 percent at up to $2192^{\circ} \mathrm{F}$.

\section{Compression Tests}

Compression tests were performed on the preload devices and seals using a state-of-the-art test rig at GRC. This test rig is capable of performing either high temperature seal compression tests or scrub tests at temperatures of up to $3000{ }^{\circ} \mathrm{F}$ using different combinations of test fixtures made of monolithic silicon carbide (Hexoloy $\alpha-\mathrm{SiC}$ ). The main components of this test rig are a servohydraulic load frame, an air furnace, and a non-contact laser extensometer (Fig. 5). The load frame has a top-mounted actuator capable of generating a load of $3300 \mathrm{lb}$ over a 6 in. stroke at rates from 0.001 to $8 \mathrm{in} . / \mathrm{sec}$. Both cyclic loading compression tests and dwell (stress relaxation) tests can be performed. Tests can be performed in either load control or displacement control. In displacement control, feedback from the LVDT (linear variable differential transformer) inside the actuator controls actuator movement. When the

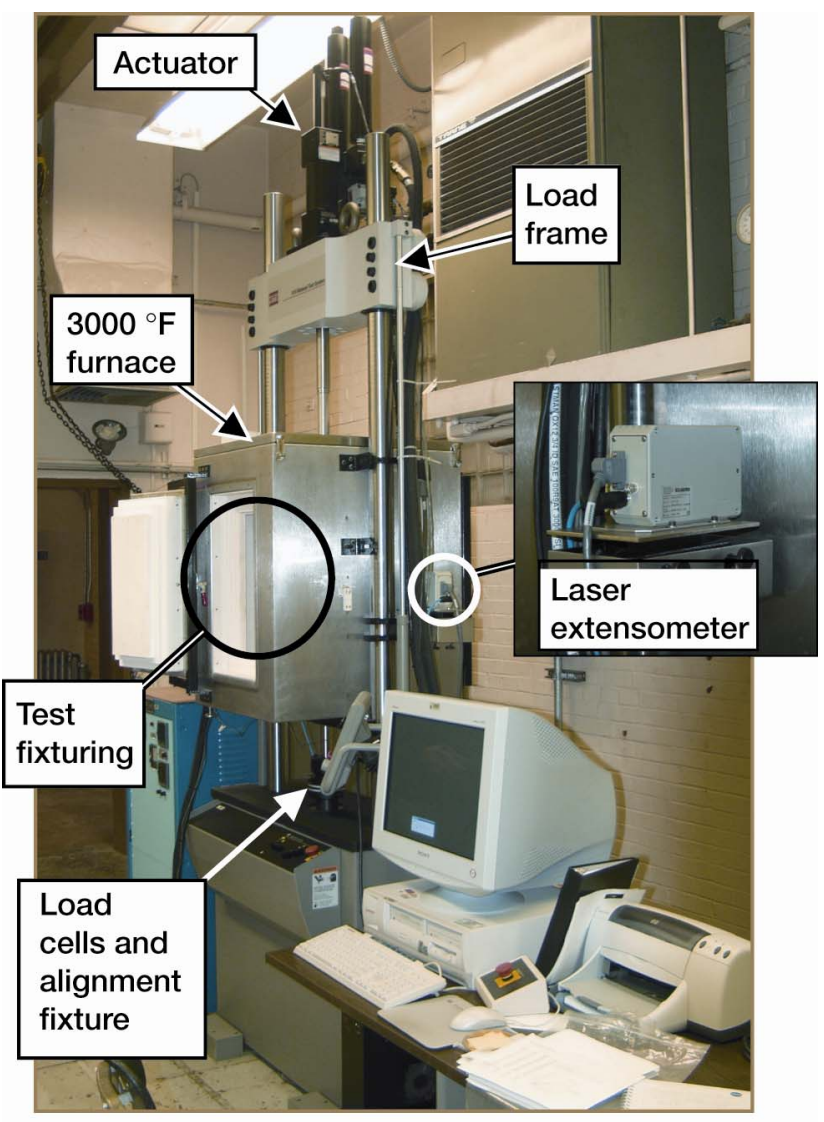

Figure 5. Photograph of hot compression and scrub test rig showing main components: load frame, high temperature furnace, and laser extensometer. LVDT is used in its narrowest calibration range of $\pm 0.5 \mathrm{in}$., it has an accuracy of $\pm 0.0017 \mathrm{in}$.

Test fixtures are configured inside the furnace so that the stationary base for each test setup sits on top of a loading rod on a load cell below the furnace. Two different load cell ranges are available, 500 or $3300 \mathrm{lb}$, depending on the seal that is being tested and the loads that are expected during a test. The $500 \mathrm{lb}$ load cell has an accuracy of $\pm 0.15 \mathrm{lb}$ ( \pm 0.03 percent of full scale), and the accuracy of the $3300 \mathrm{lb}$ load cell is $\pm 2.64 \mathrm{lb}$ ( \pm 0.08 percent of full scale). The load cells are used to measure compressive loads applied to the seals during a compression test or frictional loads on the seals during scrub testing. The $500 \mathrm{lb}$ load cell was used for all of the tests presented in the current study.

Compression tests were performed inside the furnace using the test set up shown in Fig. 6. These tests were performed to determine the resiliency and stiffness of the preload devices and to generate load versus displacement (i.e., linear compression) data. Test specimens were installed into a holder that rested on the stationary base described above. A movable platen attached to the actuator was translated up and down to load and unload the test 


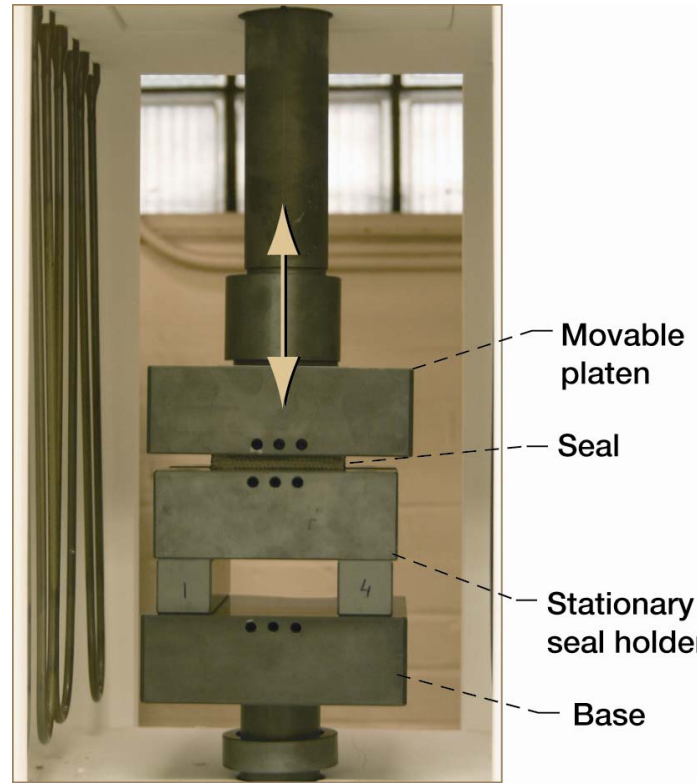

Figure 6. Hot compression test fixture setup. specimens. The laser extensometer was used to measure the amount of compression during testing (Fig. 5). The laser system has a measurement range of up to $2 \mathrm{in}$. and an accuracy of \pm 0.00025 in. Additional details for this test rig can be found in the paper by Dunlap et al. ${ }^{3}$

In a previous study by Dunlap et al. ${ }^{4}$ a series of compression tests were performed on individual silicon nitride compression springs at both room temperature and $2000{ }^{\circ} \mathrm{F}$. In the current study, compression tests were performed at 2200 and $2500^{\circ} \mathrm{F}$ to further examine spring performance at temperatures beyond the maximum use temperature suggested by the manufacturer. In addition, dwell tests were performed on the standard silicon nitride springs in which they were held in compression for 90 minutes at 2000 and $2200{ }^{\circ} \mathrm{F}$ to evaluate the creep performance of the springs.

Compression tests were also performed with 31 wafer seals on top of a set of silicon nitride springs (modified spring design) to see how they performed together. Four springs were placed below the wafers with their centers 1.15 in. apart. A thin load transfer element (0.06-in.-thick silicon carbide) was placed between the springs and the wafers to distribute the load from the four springs to the wafers. In the previous study by Dunlap et al. $^{4}$ these tests were performed at room temperature and at $1600{ }^{\circ} \mathrm{F}$ so that the results would correspond with those for scrub tests performed on the wafers at those temperatures. In the current study, these tests were performed at $2000^{\circ} \mathrm{F}$ so that the results would correspond with those for a new scrub test performed on the wafers at $2000^{\circ} \mathrm{F}$. The exact amount of compression applied in each test is summarized in the Results and Discussion section.

Test specimens were typically loaded and unloaded for a total of 10 cycles for each test. Each load cycle consisted of loading a test specimen at a rate of $0.001 \mathrm{in} . / \mathrm{sec}$ to the specified amount of compression, holding at that compression level for 30 to $60 \mathrm{sec}$, and then unloading at $0.001 \mathrm{in}$./sec to the starting point. There was no hold time after the specimen was unloaded between load cycles. At the start of each test, the movable platen was lowered until it was in contact with the test specimen. For the tests performed on individual springs, "contact" was defined when there was a load of $0.1 \mathrm{lb}$ on the test specimen, while a load of $0.2 \mathrm{lb}$ was used to define contact for the tests with wafers on top of the springs.

\section{Scrub Tests}

The main test rig that was used for the compression tests was also used to perform scrub tests on the seals using a different set of test fixtures (Fig. 7). In the previous study by Dunlap et al. ${ }^{4}$ scrub tests were performed at room temperature and at $1600^{\circ} \mathrm{F}$ to evaluate seal wear rates and frictional loads as the seals were scrubbed against Inconel 625 rub surfaces. In the current study, a scrub test was performed at $2000^{\circ} \mathrm{F}$ in which the wafer seals were scrubbed against silicon carbide rub surfaces. These rub surfaces had an average surface roughness before testing of $29 \mu \mathrm{in}$. in the scrubbing direction and $25 \mu \mathrm{in}$. in the transverse direction. The seals were installed in grooves in two stationary seal holders on either side of a pair of movable rub surfaces. The rub surfaces were assembled in a holder that was connected through the upper load train to the actuator. The gaps between the rub surfaces and the seals were set by spacer shims in front of and behind the seal holders. A gap size of 0.135 in. was used for these tests.

Four silicon nitride compression springs (modified spring design) were installed in the bottom of each seal groove to keep the wafer seals preloaded against both rub surfaces. As with the compression tests, the springs were installed on 1.15-in. centers below the wafers, and a load transfer element was placed on top of the springs to support the wafers and distribute the load from the springs. Thirty two wafers were installed into each seal holder to fill the 4-in.-long seal grooves. The amount of compression on the seals and springs $(0.028 \mathrm{in}$.) was set through an interference fit between the seals and the rub surfaces resulting in a preload of about $2 \mathrm{lb}$ per inch of seal.

During these tests, the seals were held in place in the holders while the rub surfaces were scrubbed up and down against them. For each load cycle a triangle wave was used with a stroke length of 1 in. in each direction and a stroke rate of $2 \mathrm{in} . / \mathrm{sec}$. There was no hold time between scrub direction changes. The seals were subjected to 


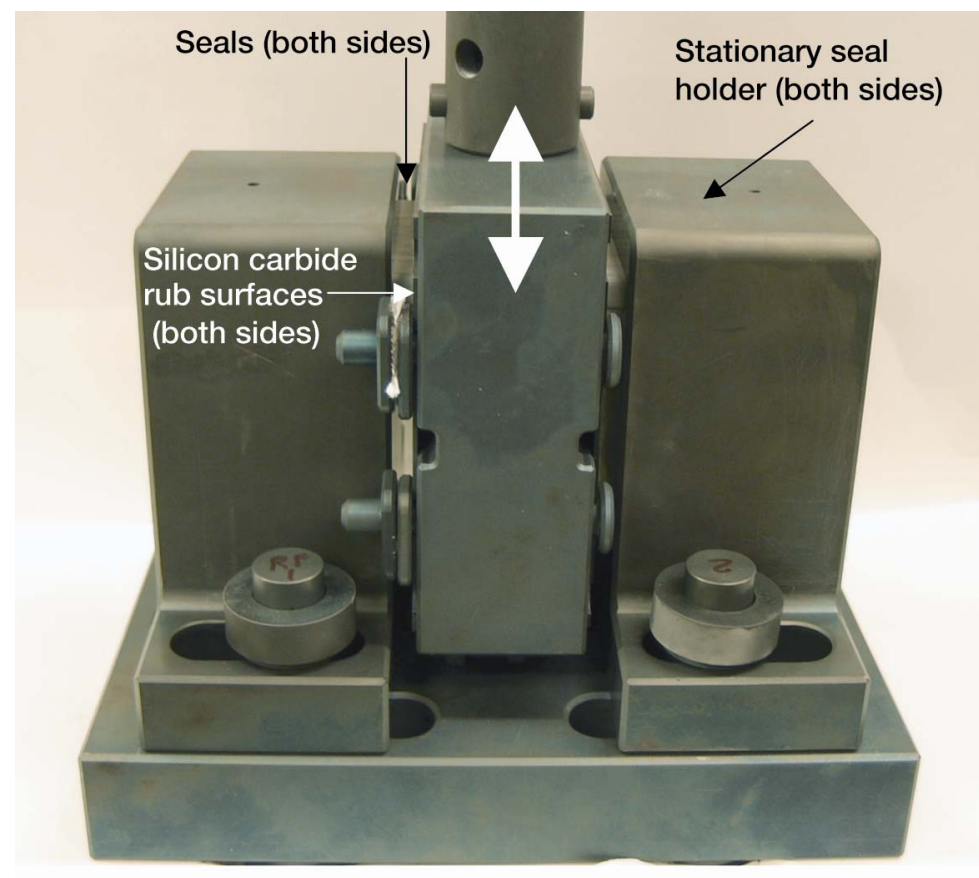

Figure 7. Hot scrub test fixture setup.
1000 scrub cycles at $1 \mathrm{~Hz}$ for a total scrub length of $2000 \mathrm{in}$. for each test. Frictional loads were measured by the load cell under the furnace below the test fixture base. Seal wear rates were determined by examining the condition of the seals before and after each test and by measuring seal weight changes and changes in flow rates.

The number of scrub cycles and scrubbing distance used for these tests were all based on requirements for a seal application in a candidate rocket-base combined cycle (RBCC) demonstrator engine. In the demonstrator engine, the seals would be scrubbed over a distance of 18 in. per mission. During engine checkout before each flight, the seals could be subjected to an additional 18 in. of scrubbing. After 25 missions this would result in a total seal scrubbing distance of 900 in. A safety factor of 2.2 was applied to achieve the 2000-in. total scrubbing distance that was used for these tests.

\section{E. Flow Tests}

Room temperature flow tests were performed in a linear flow fixture shown schematically in Fig. 8. The flow fixture was designed so that seals of different diameters could be tested in removable cartridges that are inserted into the main body of the test fixture. Seals can be tested in this fixture with different seal gaps and under different amounts of linear compression.

Seals were tested in a groove in the seal cartridge shown in Fig. 8. Tests were performed on the wafer seals with four silicon nitride springs (modified spring design) mounted on 1.15-in. centers preloading the wafers from behind using the load transfer element. Thirty wafers were used for each flow test so that the total seal length was 3.75 in. in the 0.502 -in.-wide groove. Preload was applied to the wafers and springs through an interference fit between the seal and the cover plate. All tests were performed with a 0.130 -in. seal gap and with the springs under

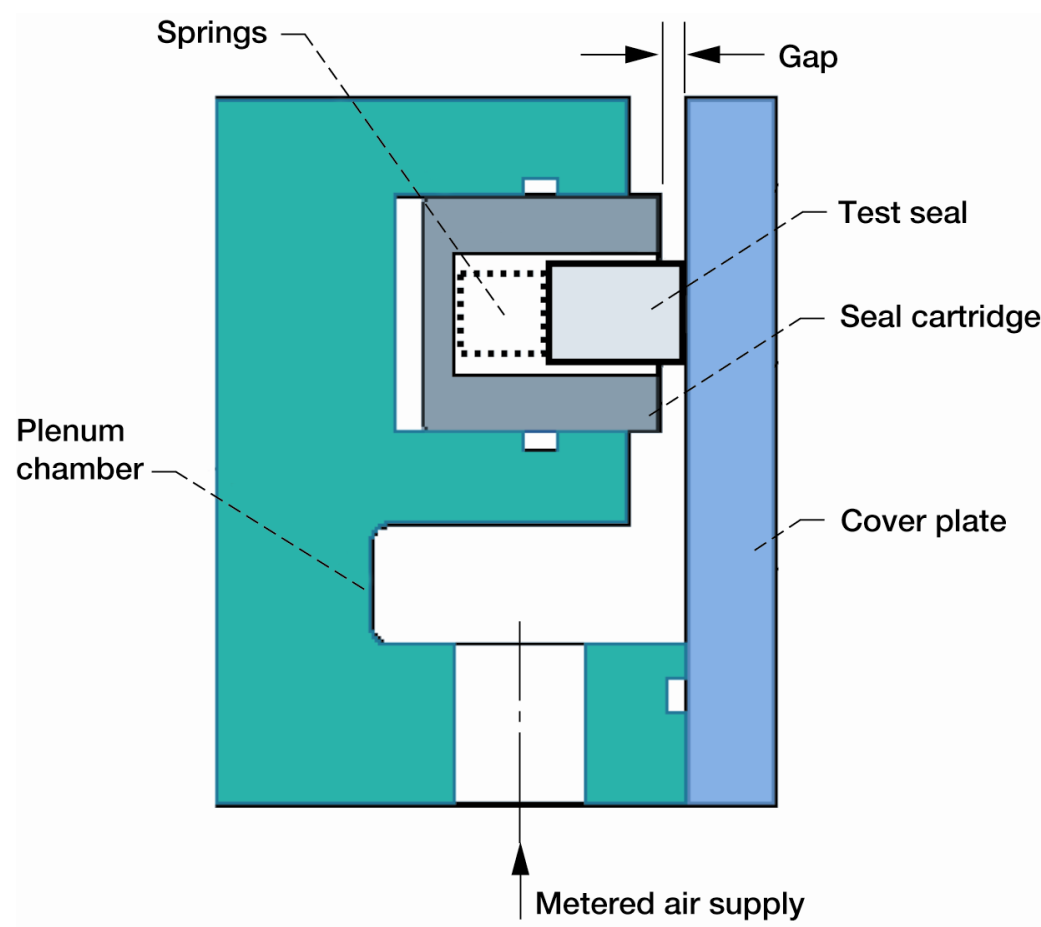

Figure 8. Cross section schematic of flow fixture. nominally 0.030 in. of compression.

During testing, flow meters upstream of the flow fixture measured the amount of flow that passed through the test seal. The maximum capacity flow meter that was used had a range of 0 to 26.5 standard cubic feet per minute (SCFM) with an accuracy of 1 percent of full scale. A pressure transducer ( 0 to 100 psid, accuracy 0.074 percent of 
full scale) upstream of the test seal measured the differential pressure across the seal with respect to ambient conditions, and a thermocouple measured the upstream temperature. For these tests, an additional pressure transducer was installed to measure the pressure behind the wafers at the bottom of the seal groove. These pressure measurements were used to examine the ability to pressurize the seals from behind to aid in preloading them against the sealing surface.

Tests were performed on the wafer seals before and after they were scrub tested at $2000{ }^{\circ} \mathrm{F}$. Primary and repeat tests were performed for each test case. More detailed descriptions of the hardware and procedure used to perform these tests can be found in the paper by Dunlap et al. ${ }^{3}$

\section{Results and Discussion}

\section{A. Compression Test Results: Silicon Nitride Compression Springs}

Figure 9 presents data for the tests performed on the modified silicon nitride compression springs. This plot includes new data for tests performed on the spring by itself at $2200^{\circ} \mathrm{F}$ and for tests performed on the wafers on top of the springs at $2000^{\circ} \mathrm{F}$. For comparison purposes, Fig. 9 also shows the results of tests performed by Dunlap et al. ${ }^{4}$ on the spring by itself at room temperature and $2000^{\circ} \mathrm{F}$ as well as tests performed for the wafers on top of the springs at room temperature and $1600{ }^{\circ} \mathrm{F}$. Figure 10 shows the results of the compression tests performed on the standard silicon nitride compression springs. This plot includes new data for tests performed at 2200 and $2500{ }^{\circ} \mathrm{F}$ as well as data recorded previously by Dunlap et al. ${ }^{4}$ for tests performed at room temperature and $2000{ }^{\circ} \mathrm{F}$. For clarity, Fig. 9 only shows the curves for load cycle 10 of each test. Figure 10 shows cycle 10 for each test as well as cycle 1 for the test performed at $2500^{\circ} \mathrm{F}$. For the tests performed on the springs by themselves, both designs were loaded to a linear compression that was about 85 percent of the maximum deflection specified by the manufacturer to avoid breaking the springs (Table 2). The standard springs were subjected to a linear compression of 0.083 in., and the modified spring design was compressed 0.036 in.

Spring constants for both spring designs are shown in Figs. 9 and 10 for each test case. The modified spring design had spring constants of $65 \mathrm{lbf} / \mathrm{in}$. at room temperature, $58 \mathrm{lbf} / \mathrm{in}$. at $2000{ }^{\circ} \mathrm{F}$, and $60 \mathrm{lbf} / \mathrm{in}$. at $2200{ }^{\circ} \mathrm{F}$, indicating that the springs were slightly less stiff at high temperatures. The elastic modulus of silicon nitride at $2200{ }^{\circ} \mathrm{F}$ is about 5 percent lower than it is at room temperature which helps explain this behavior. ${ }^{7}$ The standard

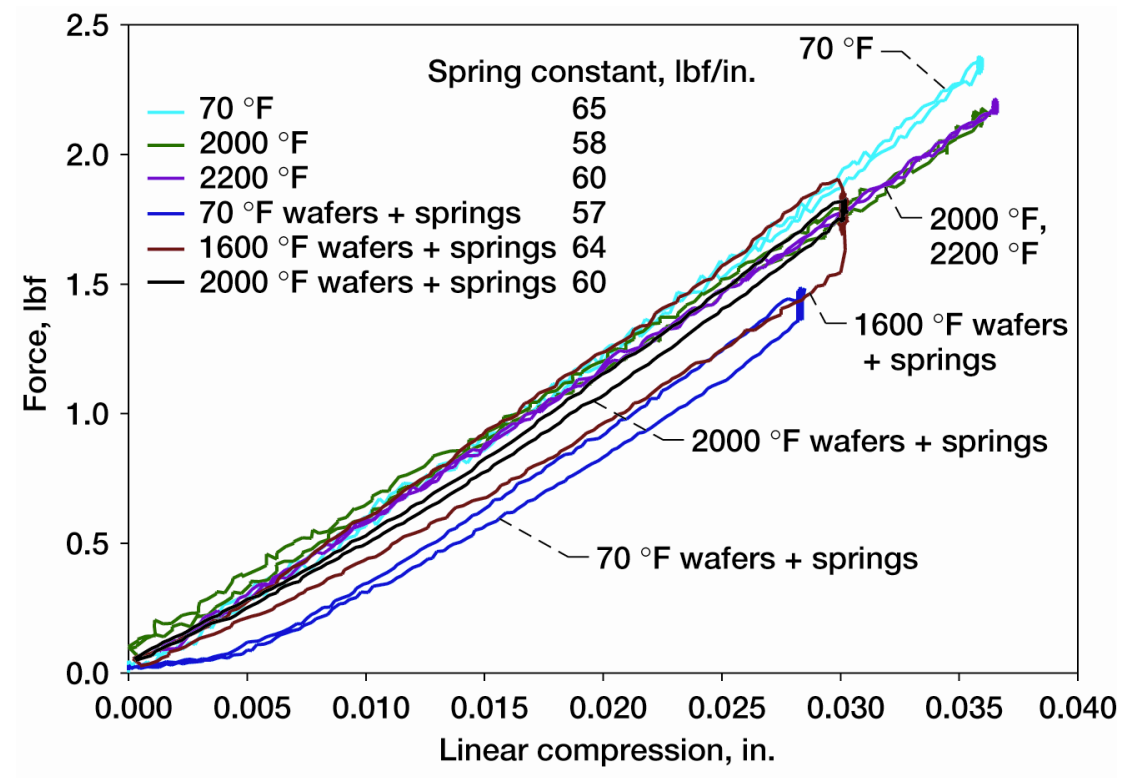

Figure 9. Load versus linear compression data for tenth load cycle on modified silicon nitride springs by themselves and for wafer seals on top of springs. (Note: Four springs were tested under the wafer seals, while only one spring was used for other tests.) 


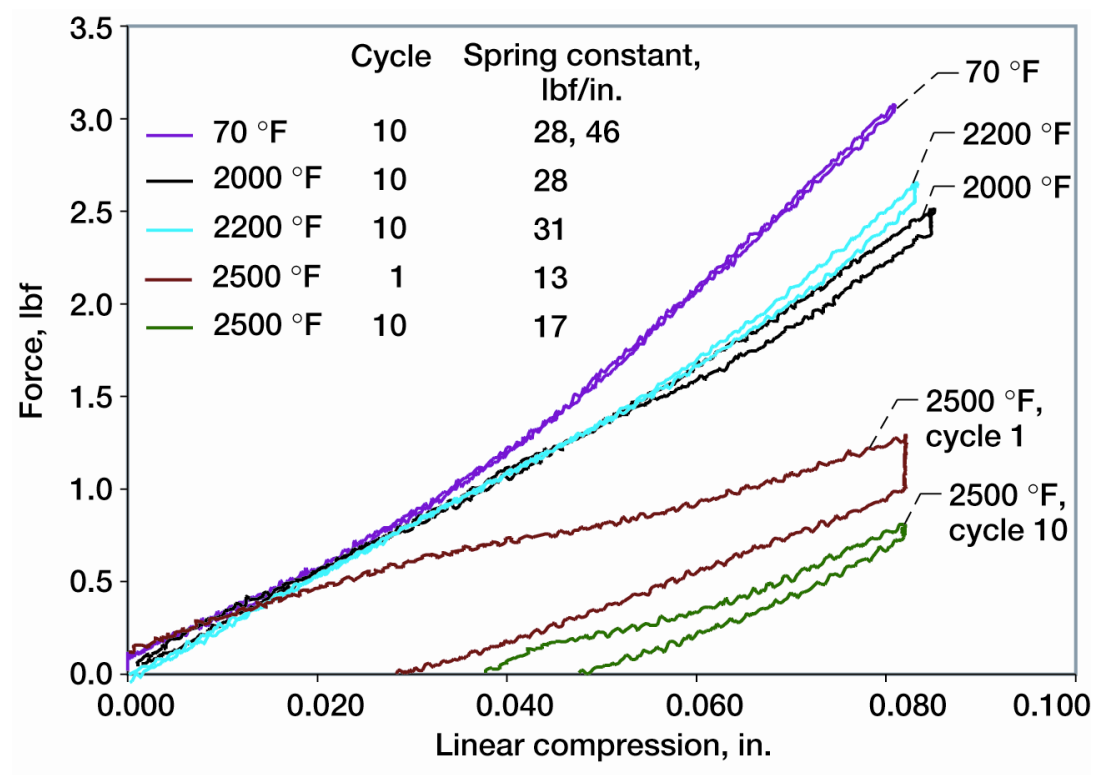

Figure 10. Load versus linear compression data for standard silicon nitride springs.

Table 3. Summary of peak loads and residual interference for silicon nitride compression springs tested by themselves as a function of temperature.

\begin{tabular}{|c|c|c|c|c|c|c|c|c|c|c|c|c|}
\hline \multirow[b]{2}{*}{ Cycle } & \multicolumn{4}{|c|}{$\begin{array}{l}\text { Peak load at dwell, } \\
\text { lbf }\end{array}$} & \multicolumn{4}{|c|}{$\begin{array}{l}\text { Residual interference } \\
\text { at start of load cycle, in. }\end{array}$} & \multicolumn{4}{|c|}{$\begin{array}{l}\text { Percent residual interference } \\
\text { at start of load cycle, percent }\end{array}$} \\
\hline & 1 & 2 & 3 & 10 & 1 & 2 & 3 & 10 & 1 & 2 & 3 & 10 \\
\hline \multicolumn{13}{|l|}{ Standard spring design } \\
\hline Room temperature & 3.17 & 3.16 & 3.18 & 3.08 & 0.083 & 0.083 & 0.083 & 0.081 & 100.0 & 99.7 & 100.0 & 100.0 \\
\hline $2000^{\circ} \mathrm{F}$ & 2.55 & 2.53 & 2.51 & 2.52 & 0.083 & 0.083 & 0.083 & 0.084 & 100.0 & 98.7 & 97.9 & 98.7 \\
\hline $2200^{\circ} \mathrm{F}$ & 2.76 & 2.73 & 2.71 & 2.62 & 0.083 & 0.083 & 0.082 & 0.082 & 100.0 & 99.6 & 99.3 & 99.5 \\
\hline $2500^{\circ} \mathrm{F}$ & 1.30 & 1.11 & 0.96 & 0.81 & 0.083 & 0.071 & 0.059 & 0.046 & 100.0 & 86.3 & 71.2 & 55.7 \\
\hline \multicolumn{13}{|l|}{ Modified spring design } \\
\hline Room temperature & 1.78 & 1.75 & 1.75 & 1.74 & 0.036 & 0.036 & 0.036 & 0.036 & 100.0 & 100.0 & 100.0 & 100.0 \\
\hline $2000^{\circ} \mathrm{F}$ & 2.29 & 2.29 & 2.27 & 2.18 & 0.036 & 0.036 & 0.035 & 0.036 & 100.0 & 98.0 & 96.9 & 100.0 \\
\hline $2200^{\circ} \mathrm{F}$ & 2.22 & 2.19 & 2.16 & 2.14 & 0.036 & 0.036 & 0.036 & 0.035 & 100.0 & 98.9 & 98.8 & 95.6 \\
\hline
\end{tabular}

spring design showed a different type of loading behavior, though, as shown in Fig. 10. Its load versus linear compression curve at room temperature had two different regions. In the linear compression range up to about $0.040 \mathrm{in}$., the standard spring had a spring constant of about $28 \mathrm{lbf} / \mathrm{in}$. From $0.040 \mathrm{in}$. to $0.083 \mathrm{in}$., the spring became stiffer with a spring constant of $46 \mathrm{lbf} / \mathrm{in}$. This type of behavior did not occur during the tests at 2000 and $2200^{\circ} \mathrm{F}$, though, as the spring constant remained at 28 and $31 \mathrm{lbf} / \mathrm{in}$. respectively throughout the test.

Table 3 summarizes the peak loads during dwell for cycles 1,2,3, and 10 as well as residual interference values for each of these cycles for all of the tests performed on the springs by themselves. Residual interference is a relative measure of how much the sealing system springs back after a given deflection. It is calculated by subtracting the amount of permanent set incurred from the maximum stroke applied by the loading platen. Permanent set is estimated by determining where the load begins to continually increase (i.e., when contact occurs between the load platen and test specimen) in the subsequent cycle. Table 3 also shows percent residual interference values for each case. Percent residual interference was defined as:

Percent residual interference $=100 *($ Total linear compression - Permanent set $) /$ Total linear compression 
For the tests performed at room temperature, $2000{ }^{\circ} \mathrm{F}$, and $2200{ }^{\circ} \mathrm{F}$, the springs exhibited basically no permanent set and close to 100 percent residual interference after 10 load cycles. There was also very little drop in load (less than 5 percent) from the first load cycle to the last cycle for each of these tests. This drop in load is also within the $\pm 0.015 \mathrm{lb}$ accuracy of the load cell used for these tests. At $2500{ }^{\circ} \mathrm{F}$, though, the springs relaxed and took on a permanent set with each successive load cycle. Figure 10 shows that even in cycle 1 the load was lower than it was for cycle 10 of the tests performed at lower temperatures. By the tenth cycle, the peak load had dropped by 37 percent and the percent residual interference was down to 55 percent. Clearly there is a point between 2200 and $2500^{\circ} \mathrm{F}$ at which the material strength falls off and causes the spring to lose resiliency.

As shown in Figs. 9 and 10, there was very little hysteresis in the load versus linear compression data at room temperature, $2000{ }^{\circ} \mathrm{F}$, and $2200{ }^{\circ} \mathrm{F}$. Although these figures only show data for the tenth load cycle, the loading and unloading portions of the curve were almost identical for all ten load cycles in each of these tests. For the test performed at $2500{ }^{\circ} \mathrm{F}$ there was more hysteresis in the loading and unloading portions of the curve, but this is to be expected based on the permanent set and loss of resiliency noted earlier.

\section{B. Compression Test Results: Seals + Silicon Nitride Compression Springs}

In addition to showing data for the silicon nitride compression springs by themselves, Fig. 9 also shows the results for the compression tests performed on a set of 31 wafer seals supported by the load transfer element and four silicon nitride springs (modified design). New data is presented for tests performed at $2000{ }^{\circ} \mathrm{F}$ as well as data previously reported by Dunlap et al. ${ }^{4}$ at room temperature and $1600{ }^{\circ} \mathrm{F}$ for comparison purposes. These tests were performed up to a maximum compression of approximately 0.030 in. The test temperatures were selected to correspond to the scrub test conditions.

The room temperature tests generated a spring constant of $57 \mathrm{lbf} / \mathrm{in}$. that was close to the spring constant for the spring by itself at room temperature. For the tests at 1600 and $2000{ }^{\circ} \mathrm{F}$, the spring constants during the loading portion of the curve increased slightly to 64 and $60 \mathrm{lbf} / \mathrm{in}$. respectively. These results were similar to the spring constant for the spring by itself at $2000^{\circ} \mathrm{F}$.

The main difference between the tests performed at room temperature and those performed at 1600 and $2000^{\circ} \mathrm{F}$ was that there was virtually no hysteresis for the room temperature tests but a small amount for the high temperature tests (Fig. 9). It is possible that during the tests at 1600 and $2000{ }^{\circ} \mathrm{F}$, there was some small amount of friction between the wafers and the side walls of the seal groove that caused this hysteresis as the wafers and springs were unloaded during each load cycle. Although there was some hysteresis in the high temperature test data, there was no permanent set or relaxation in these springs for any of the tests. This is to be expected because the wafers are solid blocks of silicon nitride, and the springs by themselves did not exhibit any permanent set during testing up to $2200{ }^{\circ} \mathrm{F}$. These results show that the silicon nitride springs show promise for use as high temperature seal preload devices.

\section{Compression Test Results: Dwell Tests on Silicon Nitride Compression Springs}

Results for the dwell tests performed on the standard silicon nitride compression springs at 2000 and $2200{ }^{\circ} \mathrm{F}$ are presented in Fig. 11 . After $1.5 \mathrm{hrs}$ at $2000{ }^{\circ} \mathrm{F}$ the load dropped from $2.3 \mathrm{lb}$ at the start of the test to just above $2 \mathrm{lb}$ at the end of the test, a decrease of about 13 percent. For the test at $2200{ }^{\circ} \mathrm{F}$ the load drop was more pronounced, falling from $2.27 \mathrm{lb}$ at the start of the test to $1.5 \mathrm{lb}$ at the end for a decrease of 34 percent over the $1.5-\mathrm{hr}$ test. In both tests the height of the springs was measured before and after each test. In each case, the springs were 0.009 in. shorter after

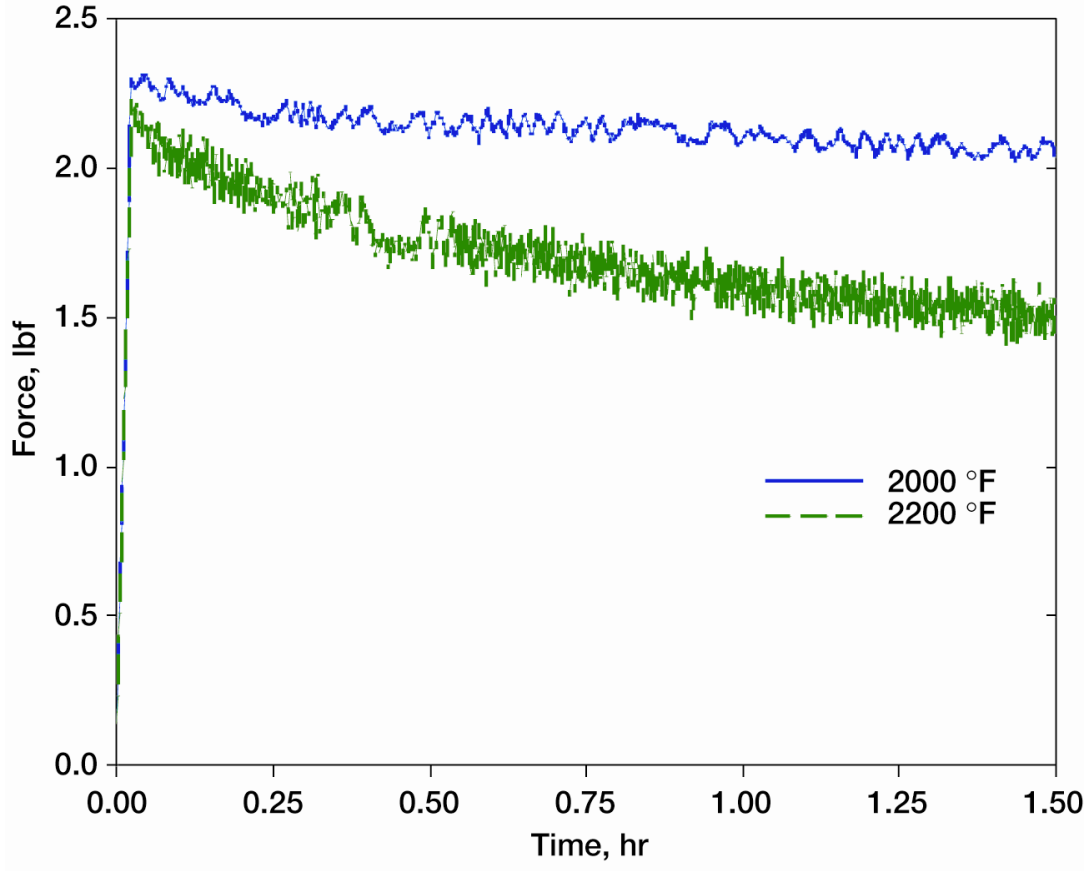

Figure 11. Load versus time data for dwell tests performed on standard silicon nitride springs at $2000{ }^{\circ} \mathrm{F}$ and $2200{ }^{\circ} \mathrm{F}$. 
the test than they were at the start of the test, indicating that the springs took on some permanent set due to creep during testing.

Table 2 shows that the approximate flight time for a candidate hypersonic engine is about 42 minutes. The dwell tests performed on the silicon nitride compression springs simulated conditions in which a sealing system including these springs would be under compression at high temperatures for two flights. The results of these tests indicate that the springs creep when loaded at temperatures above $2000^{\circ} \mathrm{F}$, but they are still able to support load. If this spring design was to be used for a high temperature seal application provisions may need to be made to ensure that the springs provide the desired preload to the seals for multiple missions. One way to do this would be to load the springs slightly beyond the desired preload initially and then allow them to creep in order to account for this slight drop in load over time at high temperatures. Another approach would be to design the seal grooves and surrounding structures to keep the spring temperature closer to $2000^{\circ} \mathrm{F}$ where less creep was observed.

The tests performed on the silicon nitride compression springs were "proof of concept" tests that showed that it is possible for a spring-like device to operate at high temperatures while still maintaining its load-bearing capabilities and resiliency. The specific spring designs that were evaluated did not meet all of the requirements described earlier for potential seal preload devices in that they were taller than the requirements, did not provide the desired 0.1 in. of stroke, and took on a permanent set at $2500{ }^{\circ} \mathrm{F}$. Although these springs did not meet all of the requirements, the spring material and design were not optimized for this application. Additional work in this area could yield a multi-use spring for $2500^{\circ} \mathrm{F}$.

\section{Scrub Test Results}

Peak frictional loads during the down stroke of each scrub cycle are presented in Fig. 12 for the scrub test performed against silicon carbide rub surfaces at $2000^{\circ} \mathrm{F}$. For comparison purposes, this figure also shows data previously reported by Dunlap et al. ${ }^{4}$ for tests performed at room temperature and $1600{ }^{\circ} \mathrm{F}$ against Inconel $625 \mathrm{rub}$ surfaces. During the $2000^{\circ} \mathrm{F}$ scrub test, the frictional loads started approximately at $7 \mathrm{lbf}$ at the beginning of the test and gradually rose as the test proceeded until reaching $12.8 \mathrm{lbf}$ by the end of the test. There was no initial load spike in the data, indicating that the seals did not stick to the rub surfaces during furnace heatup. The seals were installed so that the springs behind them provided a load against the silicon carbide rub surfaces of about $1.7 \mathrm{lbf} / \mathrm{in}$. over both 4-in. seal lengths. This resulted in a total normal load of $13.6 \mathrm{lbf}$ during testing. Based on this normal load, the friction coefficient rose from about 0.5 at the start of the test to just less than 1.0 by the end.

Figure 12 shows that the frictional loads for the silicon nitride wafers against the silicon carbide rub surfaces at $2000{ }^{\circ} \mathrm{F}$ were comparable to those recorded for the room temperature test against the Inconel 625 rub surfaces and slightly lower than those for the $1600^{\circ} \mathrm{F}$ test. The friction coefficients presented above for the $2000{ }^{\circ} \mathrm{F}$ test were also similar to those reported by Dunlap et al. $^{4}$ for the lower temperature scrub tests.

After the $2000^{\circ} \mathrm{F}$ scrub test was completed, the seals and rub surfaces were inspected for signs of damage. Figure 13 shows the seals before and after scrubbing and the silicon carbide rub surface after the test. The seals showed little if any damage after testing. None of the wafers were chipped or broken during testing, and the total weight of both wafer sets before and after testing was almost identical. Small amounts of wear debris from the rub surface can be seen on some of the wafers in places that correspond to areas on the rub surface where similar debris is located. It is believed that this wear debris is due to abrasion of the oxide layer that formed on the silicon carbide rub surfaces during testing.

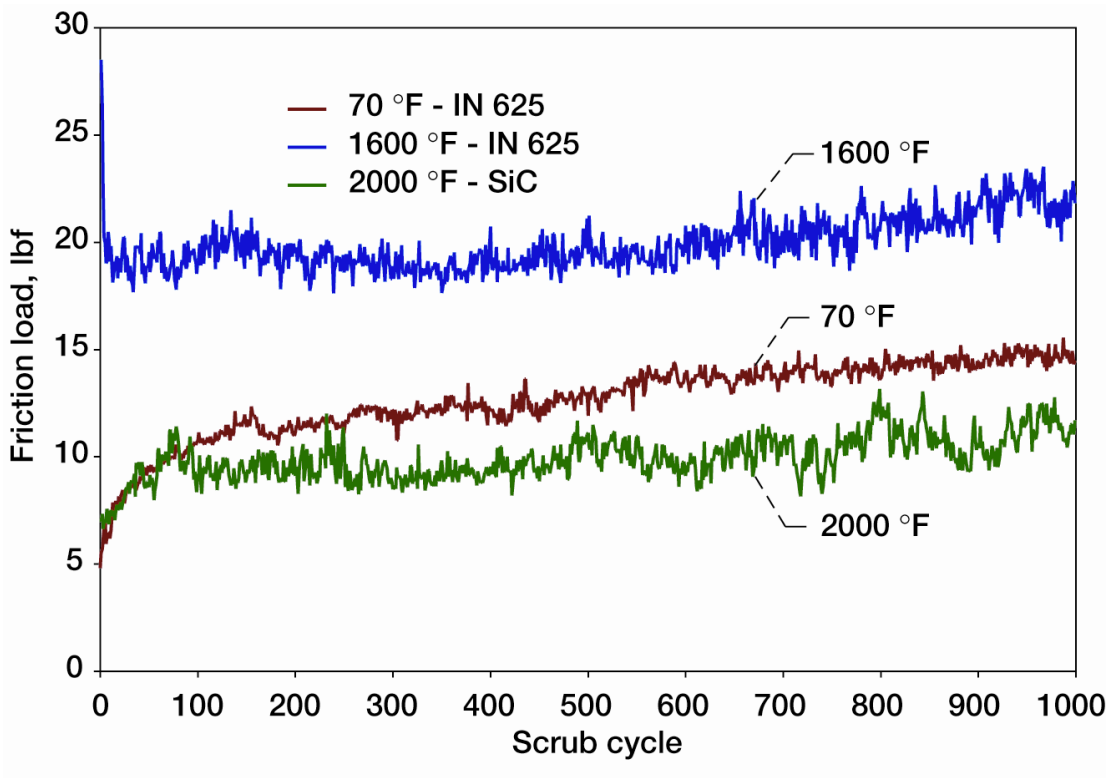

Figure 12. Peak frictional loads during down stroke of each scrub cycle for scrub tests performed at room temperature, $1600{ }^{\circ} \mathrm{F}$, and $2000^{\circ} \mathrm{F}$. 
Before this scrub test, the average surface roughness of the rub surfaces was about $29 \mu \mathrm{in}$. in the scrubbing direction and $25 \mu \mathrm{in}$. in the transverse direction. After testing, the average surface roughness in the scrubbing direction was about the same at $27 \mu$ in. but had risen to $38 \mu \mathrm{in}$. in the transverse direction. This slight increase in surface roughness during testing likely contributed to the increase in frictional forces as the test proceeded.

Overall, the silicon nitride wafers performed well during the $2000^{\circ} \mathrm{F}$ scrub test. They survived the test completely intact with no signs of chipping or other damage. Similar performance was reported by Dunlap et al. ${ }^{4}$ for the tests performed at room temperature and $1600{ }^{\circ} \mathrm{F}$. Silicon carbide wafer seals tested during the NASP program were much more damage-prone and chipped during static flow testing even without scrubbing. The silicon nitride wafers tested herein appear to be much more robust and damage-resistant.

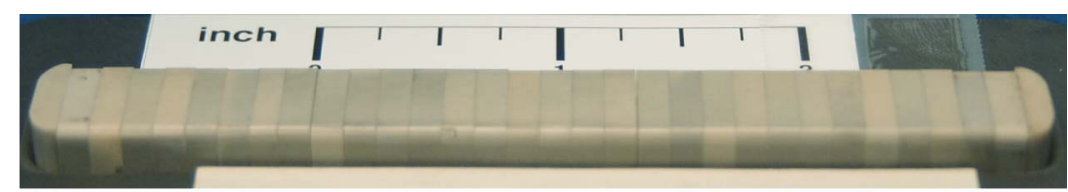

(a)

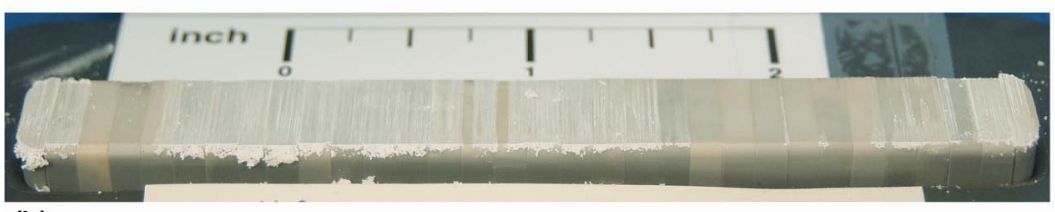

(b)

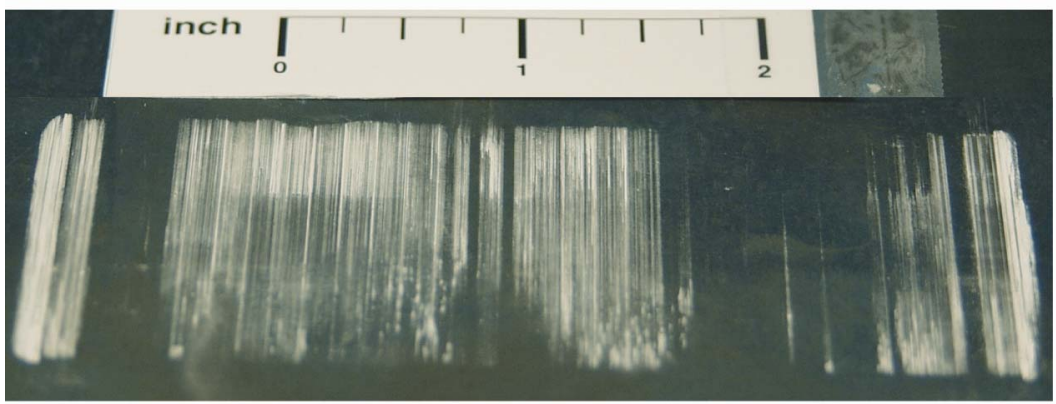

(c)

Figure 13. Photographs of seals (a) before and (b) after $2000^{\circ} \mathrm{F}$ scrub test and (c) silicon carbide rub surface after testing.

\section{E. Flow Test Results}

Room temperature flow data for the wafer seals before and after scrub testing are presented in Fig. 14. This plot includes new data for tests performed on the seals before and after the $2000{ }^{\circ} \mathrm{F}$ scrub test as well as data previously reported by Dunlap et al. ${ }^{4}$ for flow tests on the seals before and after scrub tests at room temperature and $1600{ }^{\circ} \mathrm{F}$. These tests were performed with four silicon nitride springs installed behind the wafers to keep them preloaded against the cover plate. Flow rates for the wafers before and after $2000^{\circ} \mathrm{F}$ scrubbing were very similar with only a slight increase in the post-scrub flow data. This is consistent with the observation that the wafers were not damaged during this scrub test. Figure 14 also shows that the flow rates before and after the $2000{ }^{\circ} \mathrm{F}$ scrub test are almost identical to those recorded before and after the $1600^{\circ} \mathrm{F}$ test. These results are encouraging because they show that the seals are still effective at blocking flow even after 1000 scrub cycles at $2000^{\circ} \mathrm{F}$.

Figure 14 does show a difference in flow behavior between the wafers scrubbed at room temperature and those scrubbed at 1600 and $2000{ }^{\circ} \mathrm{F}$. After performing flow tests on the seals that were scrubbed at room temperature, it was noticed that the wafers were not as uniform height-wise (i.e., 0.92-in. dimension) as desired. The wafers exhibited height variations of approximately 0.001 in. To determine the effects of tighter dimensional height control, wafer stacks with a height tolerance of 0.0005 in. were used for the 1600 and $2000^{\circ} \mathrm{F}$ scrub tests. As shown in Fig. 14, this improvement in control of wafer heights resulted in about a three-fold reduction in flow rates.

The wafer seal flow rates presented in Fig. 14 are much lower than those for braided rope seals tested under the same conditions. ${ }^{3}$ For example, at a pressure differential of $100 \mathrm{psid}$ the flow rate for a 0.6 -in.-diameter braided rope seal with a core of uniaxial ceramic fibers (AC1 design) was $11 \mathrm{SCFM} / \mathrm{in}$. with the seal under 20 percent compression. For the same setup, a 0.565 -in.-diameter seal with a core composed of smaller braided rope seals braided together ( $\mathrm{BC} 1$ design) had a flow rate of $22 \mathrm{SCFM} /$ in. Both of these flow rates are much higher than those for the wafer seals. Compared to the flow rates at 100 psid for the wafers scrub tested at room temperature, the flow rate for the $\mathrm{AC} 1$ design was over 10 times higher and the rate for the $\mathrm{BC} 1$ design was 21 times higher. If the results for the wafers scrub tested at $2000^{\circ} \mathrm{F}$ are used as the basis for comparison, the $\mathrm{AC} 1$ design rate was 32 times higher and the $\mathrm{BC} 1$ rate was 64 times higher. In all cases, the wafer seals were much more effective at blocking flow than the braided rope seals were.

For the flow tests that were performed on the wafers before and after the $2000{ }^{\circ} \mathrm{F}$ scrub test, a new pressure measurement was made that was not recorded in the previous flow tests. This pressure measurement allowed the 


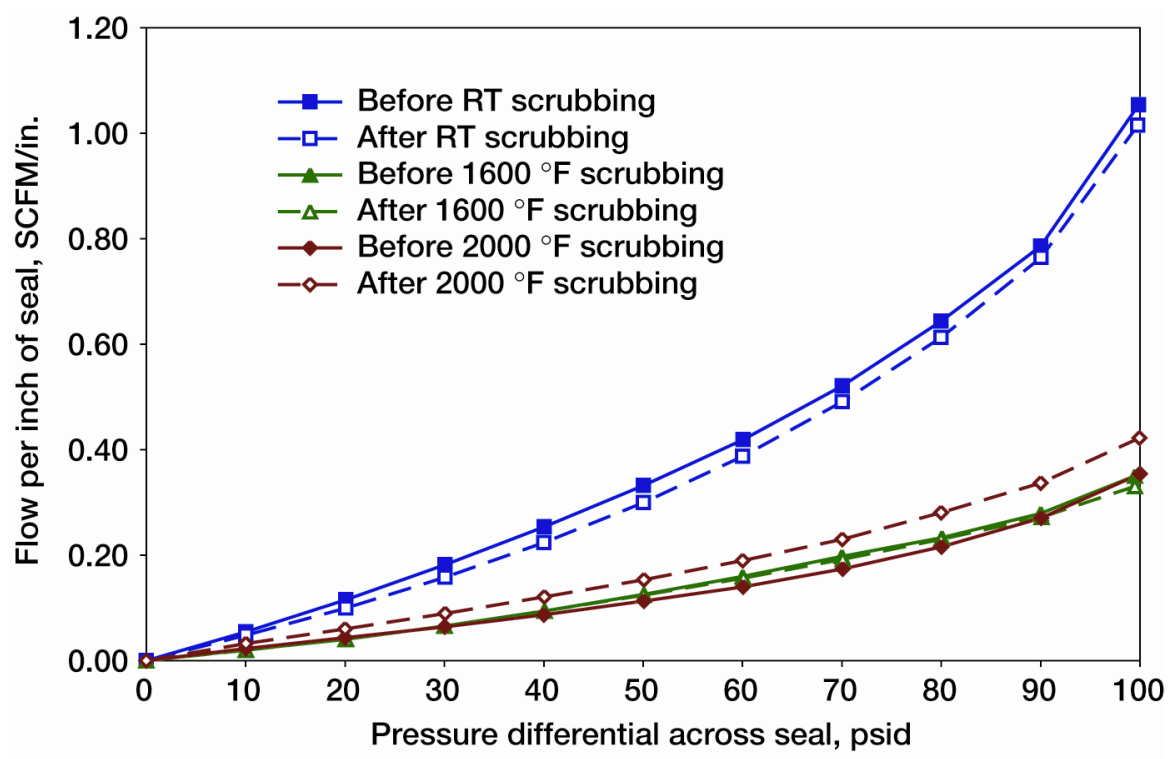

Figure 14. Wafer seal flow rates versus pressure differential before and after scrub testing. Results shown for scrub tests at room temperature (nominal 0.001 -in. wafer height tolerance, 0.135 -in. gap), $1600{ }^{\circ} \mathrm{F}$ (nominal 0.0005 -in. wafer height tolerance, 0.135 -in. gap), and $2000^{\circ} \mathrm{F}$ (nominal 0.0005 -in. wafer height tolerance, 0.130 -in. gap).

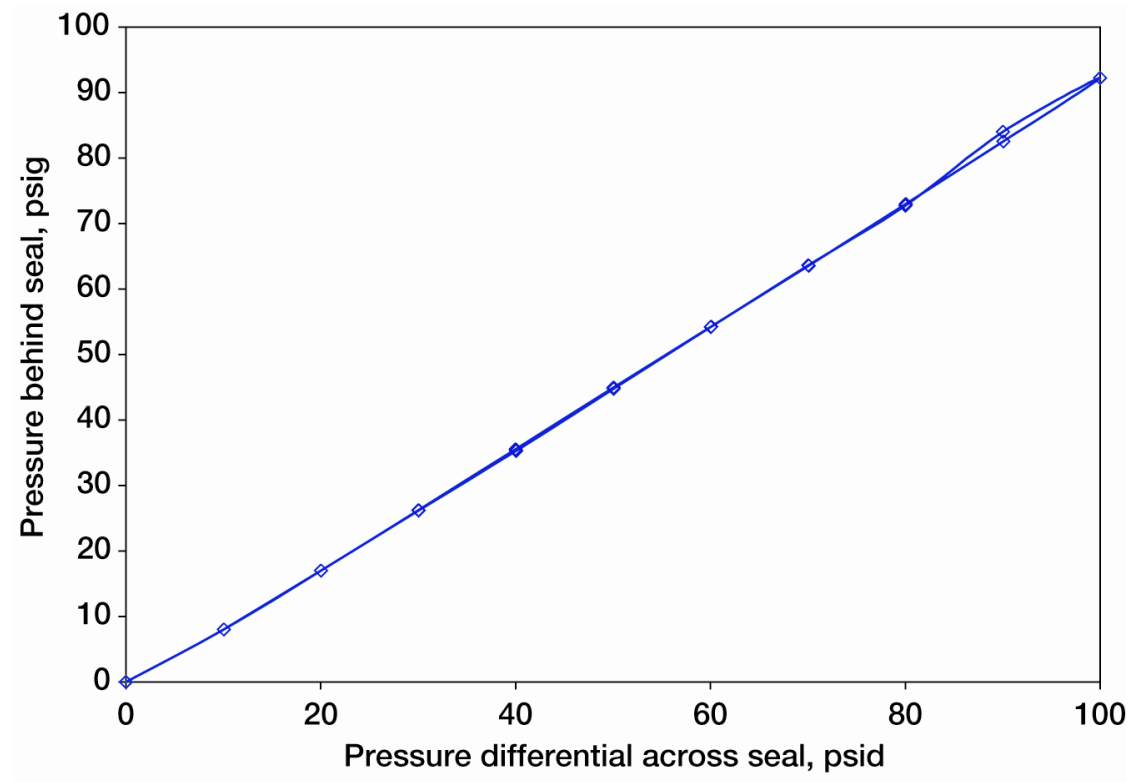

Figure 15. Pressure behind wafer seals versus pressure differential across seals for wafers scrub tested at $2000{ }^{\circ} \mathrm{F}$ with 0.130 -in. seal gap.

pressure behind the wafers to be recorded as a function of the differential pressure across the seals. Figure 15 presents pressure data behind the wafer seals versus the pressure differential across the seals for the flow test performed on the wafers that were scrub tested at $2000^{\circ} \mathrm{F}$. This plot shows a linear relationship between these pressures such that the pressure behind the seals was equal to about 93 percent of the pressure differential across the seals. The pressure behind the seals serves as a "seal activating" pressure that augments the preload devices to further preload the seals against the sealing surface and keep them in contact with it. This seal activating pressure phenomenon for wafer seals was reported previously by Steinetz. ${ }^{8}$ 


\section{Summary and Conclusions}

A variety of high temperature structural seals were developed during the NASP program including ceramic wafer seals. However, those seals fell short of some design goals and could not be adequately matured due to program termination. Requirements for future advanced hypersonic engines are similarly very demanding, and stateof-the-art seals do not meet these requirements. To address these shortfalls, advanced seals are being developed under NASA's NGLT program. Shortfalls that were investigated in the current study included a loss of seal resiliency with load cycling at high temperatures, seal durability, and seal flow blocking ability. In an effort to address these shortfalls, modern ceramic wafer seal materials and seal preload devices were evaluated in a series of compression, scrub, and flow tests. Based on the results of these tests, the following conclusions were made:

1. Silicon nitride wafer seals were more robust and damage-resistant than wafers that were tested during the NASP program. There were no signs of damage after the silicon nitride wafers were scrubbed against silicon carbide rub surfaces at $2000^{\circ} \mathrm{F}$ for 2000 in. of scrubbing (1000 cycles). None of the wafers were chipped or broken, and the total weight of each wafer set before and after testing was almost identical. Friction coefficients between the wafers and the silicon carbide rub surfaces were rather high, though, so work must be done to find ways to minimize these frictional forces.

2. Silicon nitride wafer seals were excellent at blocking flow even after 1000 scrub cycles at $2000{ }^{\circ} \mathrm{F}$. Flow rates for the wafers before and after scrubbing were almost identical and were up to 32 times lower than those recorded for the best braided rope seal flow blockers.

3. Silicon nitride compression springs continue to show promise as high temperature seal preload devices. After repeated loading at temperatures up to $2200{ }^{\circ} \mathrm{F}$ the springs showed excellent resiliency and little hysteresis. These spring designs have not been optimized for this application, though, and additional work must be done to develop spring materials and designs for multiple uses at temperatures up to $2500^{\circ} \mathrm{F}$.

\section{References}

${ }^{1}$ Steinetz, B.M., DellaCorte, C., Machinchick, M., Mutharasan, R., Du, G., Ko, F., Sirocky, P.J., and Miller, J.H., "High Temperature Dynamic Engine Seal Technology Development," NASA TM-105641, April 1992.

${ }^{2}$ Steinetz, B.M., "Evaluation of an Innovative High Temperature Ceramic Wafer Seal for Hypersonic Engine Applications," NASA TM-105556, February 1992.

${ }^{3}$ Dunlap, P.H., Steinetz, B.M., DeMange, J.J., and Taylor, S.C., "Toward an Improved Hypersonic Engine Seal," NASA TM-212531, AIAA-2003-4834, July 2003.

${ }^{4}$ Dunlap, P.H., Steinetz, B.M., and DeMange, J.J., "High Temperature Propulsion System Structural Seals for Future Space Launch Vehicles," NASA/TM-2004-212907, January 2004.

${ }_{5}^{5}$ Steinetz, B.M. and Sirocky, P.J., "High Temperature Flexible Seal,” United States Patent 4,917,302 issued April 17, 1990.

${ }^{6}$ Steinetz, B.M., "Evaluation and Ranking of Candidate Ceramic Wafer Engine Seal Materials," NASA TM-103795, May 1991.

${ }^{7}$ Silicon Nitride Ceramic Spring product literature, NHK Spring Co., Ltd., KK9502-6-1P, pp. 3-4.

${ }^{8}$ Steinetz, B.M., "High Temperature Performance Evaluation of a Hypersonic Engine Ceramic Wafer Seal," NASA TM-103737, April 1991. 



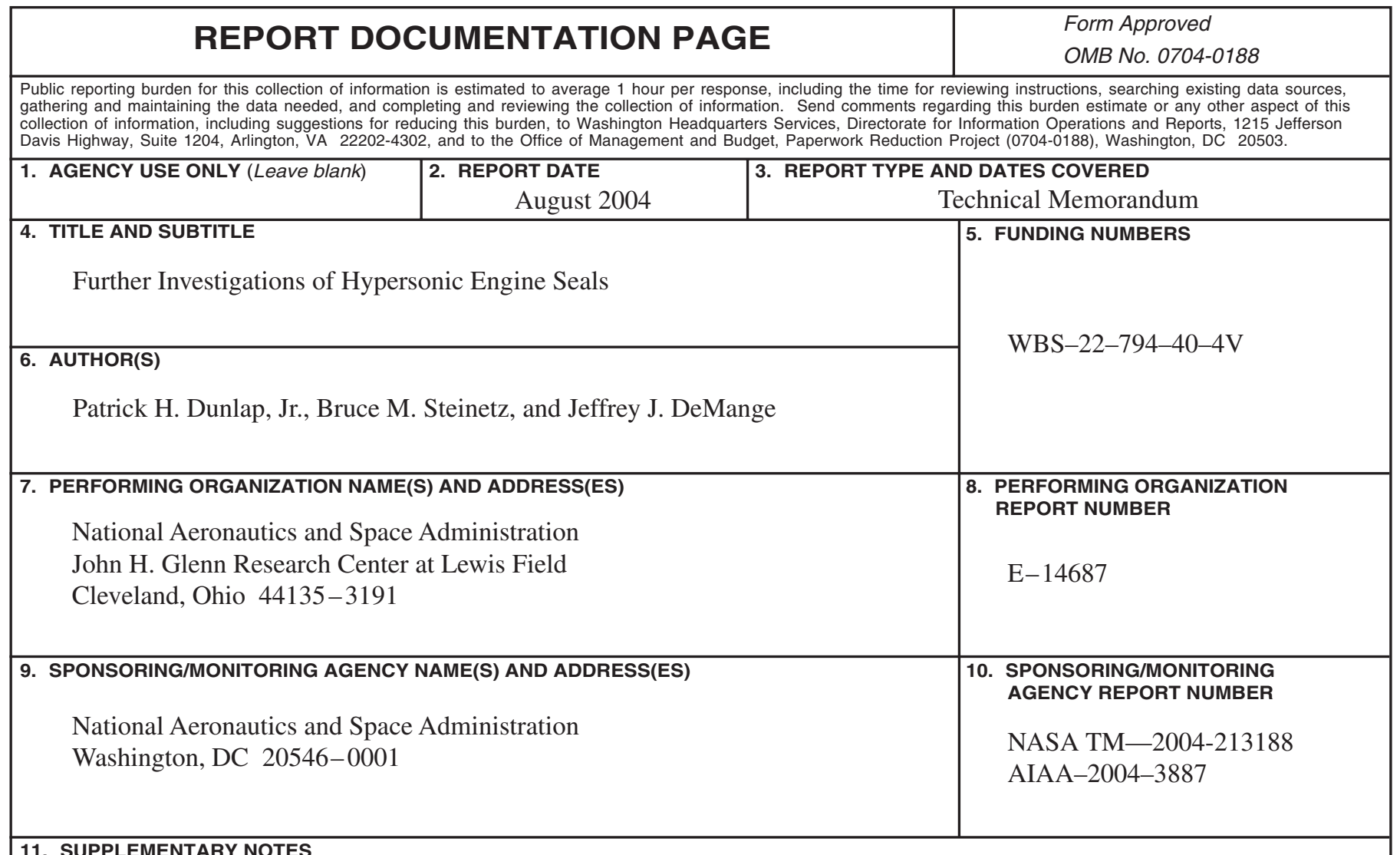

\section{SUPPLEMENTARY NOTES}

Prepared for the 40th Joint Propulsion Conference and Exhibit cosponsored by AIAA, ASME, SAE, and ASEE, Fort Lauderdale, Florida, July 11-14, 2004. Patrick H. Dunlap, Jr. and Bruce M. Steinetz, NASA Glenn Research Center; and Jeffrey J. DeMange, University of Toledo, 2801 W. Bancroft Street, Toledo, Ohio 43606-3390. Responsible person, Patrick H. Dunlap, Jr., organization code 5950, 216-433-3017.

12a. DISTRIBUTION/AVAILABILITY STATEMENT 12b. DISTRIBUTION CODE

Unclassified - Unlimited

Subject Category: 37

Distribution: Nonstandard

Available electronically at http://gltrs.grc.nasa.gov

This publication is available from the NASA Center for AeroSpace Information, 301-621-0390.

13. ABSTRACT (Maximum 200 words)

Durable, flexible sliding seals are required in advanced hypersonic engines to seal the perimeters of movable engine ramps for efficient, safe operation in high heat flux environments at temperatures of 2000 to $2500^{\circ} \mathrm{F}$. Current seal designs do not meet the demanding requirements for future engines, so NASA's Glenn Research Center is developing advanced seals and preloading devices to overcome these shortfalls. An advanced ceramic wafer seal design and two silicon nitride compression spring designs were evaluated in a series of compression, scrub, and flow tests. Silicon nitride wafer seals survived 2000 in. $(50.8 \mathrm{~m})$ of scrubbing at $2000^{\circ} \mathrm{F}$ against a silicon carbide rub surface with no chips or signs of damage. Flow rates measured for the wafers before and after scrubbing were almost identical and were up to 32 times lower than those recorded for the best braided rope seal flow blockers. Silicon nitride compression springs showed promise conceptually as potential seal preload devices to help maintain seal resiliency.

14. SUBJECT TERMS

15. NUMBER OF PAGES

Seals; Flow; Design; Test; High temperature

20

16. PRICE CODE

\begin{tabular}{|c|c|}
\hline $\begin{array}{c}\text { 17. SECURITY CLASSIFICATION } \\
\text { OF REPORT } \\
\text { Unclassified }\end{array}$ & $\begin{array}{c}\text { 18. SECURITY CLASSIFICATION } \\
\text { OF THIS PAGE } \\
\text { Unclassified }\end{array}$ \\
\hline
\end{tabular}

NSN 7540-01-280-5500

19. SECURITY CLASSIFICATION
OF ABSTRACT
Unclassified

Standard Form 298 (Rev. 2-89)

Prescribed by ANSI Std. Z39-18 298-102 

